ROCZNIK PRZEMYSKI t. 57

LITERATURA I JEZYK z. 2 (25) 2021

MONIKA MACIEWICZ (Przemyśl)

ORCID: 0000-0002-6835-8784

\title{
WIANKI I WIEŃCE W KULTURZE LUDOWEJ - SYMBOLIKA I MAGIA. ZARYS PROBLEMATYKI
}

\begin{abstract}
GARLANDS AND WREATHS IN FOLK CULTURE - SYMBOLISM AND MAGIC. AN OUTLINE
\end{abstract}

The paper analyzes symbolic and magical significance of garlands and wreaths in folk culture. It takes into consideration their shapes and component parts as cultural codes. It presents examples of using woven plants in folk practices, both in rites of passage and in magical activities (fortune-telling, protective magic). It also includes basic analysis of the symbol of a garland in folk songs.

Keywords: garland, wreath, symbol, apotropeion, folk culture, magic

Słowa kluczowe: wianek, wieniec, symbol, apotropeion, kultura ludowa, magia

Kultura ludowa obfituje w liczne nośniki znaczeń symbolicznych. Stanisława Niebrzegowska-Bartmińska sklasyfikowała je jako: przedmioty rytualne, czynności, muzyka, zabawa i taniec, postacie, czas, przestrzeń oraz kod werbalny'. Tematem niniejszego tekstu jest symboliczne i magiczne znaczenie przedmiotu rytualnego - wieńca oraz jego deminutivum (wianka). Artykuł opiera się na kwerendzie bibliograficznej obejmującej materiały z terenu całej Polski, począwszy od XIX w. aż po czasy współczesne. Kody kulturowe są ze sobą powiązane i wzajemnie się warunkują, podobnie jest z motywem wianka, który należy interpretować w kontekście czasu (m.in. sakralnego), czynności (rytuałów, działań magicznych), przekazu werbalnego, a także przestrzeni (ze względu na jego kształt).

\section{Symbolika wianka i wieńca jako koła}

Definicja wieńca jednoznacznie wskazuje kształt koła, ewentualnie półkola, co ma niebagatelne znaczenie w jego interpretacji. W Stowniku języka polskiego pod redakcją Witolda Doroszewskiego czytamy, iż wieniec to: „splot kwiatów,

${ }^{1}$ S. Niebrzegowska-Bartmińska, Symbolika płodnościowa w polskim folklorze, „Etnolingwistyka. Problemy Języka i Kultury” 2016, t. 28, s. 208. 
gałązek, ziół zwinięty w kółko”, podane są też kolejne znaczenia: ,pewna liczba przedmiotów nanizanych na sznurek, związanych kolisto” oraz „o czymś kolistym, półokrągłym, zbliżonym kształtem do koła, okalającym co półkolem, otaczającym co dokoła"2. W Stowniku języka polskiego PWN znajdują się następujące definicje wieńca: „1. koło uplecione z kwiatów, liści, kłosów itp.; 2. kolisty przedmiot lub szereg przedmiotów nanizanych na coś, związanych lub splecionych w kształcie koła; 3 . grupa osób lub rzeczy otaczających kogoś lub coś i tworzących krąg"’3.

Piotr Kowalski zwraca uwagę, że kształt wianka w dużej mierze decyduje o jego funkcji, ponieważ koło to „,idealna figura geometryczna, stanowi symboliczne odwzorowanie takiego imago mundi, w którym najważniejszymi cechami są: pełnia, harmonia, zamkniętość, brak zróżnicowań”4 . Co więcej, „zamknięcie koła, odgraniczenie od reszty świata i mediacyjność punktu centralnego nie tylko służy izolowaniu (np. w celach ochronnych), ale także zmienia status tego, co znajduje się wewnątrz granic ustanowionych przez okrąg"5. Zatem użycie kolistego rekwizytu w ramach określonego kodu kulturowego może oznaczać zmianę statusu lub stanowić sygnał o chęci takiej zmiany. Natomiast ze względu na to, że stanowi on symboliczne oddzielenie pewnej przestrzeni, wyodrębnienie jej, izolację, nabiera również cech apotropeicznych.

W Słowniku symboli Władysława Kopalińskiego odnajdujemy liczne znaczenia koła lub okręgu jako symbolu „Boga, bóstwa, wieczystego prawa, praformy; świata zjawisk; Kosmosu, nieskończoności, wieczności, absolutu, doskonałości, doskonałego kształtu, równowagi, wewnętrznej jedności i harmonii materii, jedności, czasu [...], regularności, ciągłości, idealnego, wiecznego ruchu, ruchu obrotowego, precyzji, kompletności, egzystencji cyklicznych; Nieba [...], Słońca; żywiołu wody; kręgu istnienia, duszy, pierwiastka duchowego (w przeciwieństwie do materialnego); własnego Ja, powrotu do siebie samego; zasady żeńskiej ochrony przed demonami; monety"6.

Jak widać, wykładni symbolicznych jest wiele, dlatego skupię się na tych związanych głównie z folklorem. Jednym z najczęstszych motywów spotykanych w różnych dziedzinach sztuki ludowej jest motyw solarny. Często przedstawiano go w postaci koła, rozety, swarzycy, swastyki, triskelionu czy krzyża równoramiennego. Znajdujemy go między innymi na wielkanocnych pisankach, powałach domów, korowajach i naczyniach. Zatem również wieniec, ze względu na kolisty kształt, możemy potraktować jako emblemat Słońca, czyli zaliczyć do

\footnotetext{
${ }^{2}$ Hasło: wieniec, [w:] Stownik języka polskiego, red. W. Doroszewski, t. 9, Warszawa 1967, s. 973.

${ }^{3}$ Hasło: wieniec, [w:] Stownik języka polskiego PWN, https://sjp.pwn.pl/sjp/wieniec;2536154. html [dostęp: 1 IX 2021].

${ }^{4}$ Hasło: wieniec, [w:] P. Kowalski, Leksykon - znaki świata. Omen, przesąd, znaczenie, Warszawa 1998, s. 590.

${ }^{5}$ Hasło: koło, [w:] ibidem, s. 231.

${ }^{6}$ Hasło: koło, [w:] W. Kopaliński, Stownik symboli, Warszawa 1990, s. 153.
} 
niezwykle popularnej symboliki solarnej, rozumianej jako sacrum. Przypisywano jej funkcje magiczne, traktowano jako rodzaj przynoszącego szczęście talizmanu. Wierzono również, że ma właściwości ochronne.

W słowniku Kopalińskiego odnajdujemy także liczne wykładnie symboliczne wieńca. Niektóre się wręcz wykluczają, na przykład niewola i wolność. Warto jednak wymienić te, które są znamienne dla kultury ludowej: ofiara, ochrona, obrona, urodzaj, siła żywotna, małżeństwo, płodność, obfitość, dobrobyt, dziewictwo, radość, wesołość, czary ${ }^{7}$.

Jak już wspomniałam, w niektórych sytuacjach wianek umownie komunikuje o statusie danej osoby, przypisywane są mu funkcje magiczne i apotropeiczne, głównie ze względu na kolisty kształt. Nie sposób jednak omawiać symboliki splotu roślin bez uwzględnienia jego składników i przypisywanej im magicznej mocy. Same zioła, które Kazimierz Moszyński nazywa za ludem „czarownymi”, odgrywały i nadal odgrywają ważną rolę ochronną, magiczną, a wręcz sprawczą, jednak uformowane $\mathrm{w}$ wieniec zyskują w ludowych wierzeniach większą siłę oddziaływania.

\section{Wianki i wieńce w praktykach kultury ludowej}

Wianek jako umowny komunikat symbolizuje dziewictwo, ale i gotowość do zmiany tego stanu. Jeśli w domostwie mieszkała panna na wydaniu, rekwizyt ten zawieszano w oknie lub na kołku przed domem 9 . Był to zwyczaj staropolski, który według Zbigniewa Kuchowicza przetrwał do czasów mu współczesnych i stanowił pozawerbalną informację dla potencjalnych kandydatów na mężów oraz ich rodzin. Ten emblemat dziewictwa był głównym atrybutem panny młodej. Najczęściej wito go z ruty, czasem łącząc ją z barwinkiem i kaliną. W późniejszym czasie zastąpiły je mirt oraz rozmaryn. Podczas „dziewiczego wieczoru”, „babskiego wieczoru”, „wianeczków” czy też „wieńczyn”, czyli w dniu poprzedzającym uroczystość zaślubin, odprawiano rytuał wicia ślubnego wieńca przez druhny z towarzyszeniem obrzędowych śpiewów. W Encyklopedii staropolskiej Zygmunta Glogera można znaleźć fragmenty owych pieśni:

\footnotetext{
Rozsypała Kasieńka

Drobną rutkę po stole.

Któż tę rutkę pozbiera,

Kasi wianek uwije? ${ }^{10}$
}

Tekst ten wskazuje rutę jako główny składnik ślubnego wianka. Jeszcze do niedawna na kobietę, która dotychczas nie wyszła za mąż, mówiono, że „sieje rutkę”

\footnotetext{
${ }^{7}$ Hasło: wieniec, [w:] ibidem, s. 458.

${ }^{8}$ K. Moszyński, Kultura ludowa Stowian, t. 2: Kultura duchowa, cz. 1, Warszawa 1967, s. 314.

${ }^{9}$ Z. Kuchowicz, Obyczaje staropolskie XVII-XVIII wieku, Łódź 1975, s. 185.

${ }^{10}$ Hasło: wieniec, wianki, [w:] Z. Gloger, Encyklopedia staropolska, t. 4, Warszawa 1903, s. $430-432$.
} 
- w tym kontekście kulturowym ów zwrot staje się zrozumiały. Po uwiciu niezbędnego atrybutu panny młodej przyszła mężatka toczyła go po stole, śpiewając pieśni obrzędowe, z których wynikało, że ów wianek nie jest przeznaczony dla nikogo z rodziny, tylko dla wybranka, a ten powinien go wykupić ${ }^{11}$. Przekazanie mężowi wianka, zgodnie $\mathrm{z}$ utrwalonym kodem kulturowym, było oznaką oddania mu dziewictwa. Państwo młodzi niekiedy wymieniali się wiankami, ponieważ także mężczyzna miał przy sobie ten rekwizyt, najczęściej przypięty do weselnego stroju. Dopiero w okresie międzywojennym stało się powszechnym, iż państwo młodzi podczas zaślubin wymieniali się obrączkami zamiast wiankami.

Symboliczną zmianą statusu kobiety, która stawała się mężatką, były oczepiny. Wtedy panna młoda pozbywała się atrybutu panieństwa i symbolicznie zakrywała włosy. Jeśli ślub zawierała wdowa, kobieta, która już urodziła dziecko, lub brzemienna, nie mogła mieć na głowie wianka. Wtedy znajdowano inne rozwiązania, by zachować pierwotne znaczenie owego substytutu dziewictwa. Oskar Kolberg, wybitny etnograf, znawca kultury ludowej, podaje, że „Gdy bierze ślub wdowa lub dziewczyna, która miała już dzieci, wianek ruciany kładzie im się nie na głowę, lecz na ramię"12. Niekiedy po prostu z niego rezygnowano. W tekście opublikowanym na stronie internetowej Muzeum Etnograficznego w Rzeszowie znajdujemy informację: „Wdowa i wdowiec, którzy powtórnie brali ślub, szli do niego z oznakami swego stanu: wdowa z głową zakrytą chustą (mogła ją jednak ozdobić zieloną gałązką), a wdowiec w odzieniu gospodarza, bez ozdób przy nakryciu głowy"13.

Obrzędowi oczepin towarzyszyły liczne pieśni. W tychże przyśpiewkach często przywoływano motyw wianka jako symbolu dziewictwa. Zauważamy więc powiązania przedmiotu rytualnego z kodem werbalnym. Co więcej, leksem wianek stał się eufemistycznym określeniem stanu sprzed inicjacji seksualnej. Jako egzemplifikacja może tu posłużyć jedna z najstarszych pieśni weselnych śpiewanych w całej Polsce podczas oczepin lub pokładzin - Pieśń o chmielu.

\footnotetext{
Żebyś ty chmielu na tyczki nie lazł,

Nie robiłbyś ty z panienek niewiast.

Oj chmielu, oj nieboże,

To na dół, to ku górze,

Chmielu nieboże.

Ale ty chmielu po tyczkach włazisz,

Niejedną pannę z wianeczka zrazisz $[\ldots]^{14}$.
}

W pieśni tej wianek stanowi synonim dziewictwa, a jego utrata ujęta jest w sposób eufemistyczny w postaci frazeologizmu „z wianeczka zrazisz”. Taką interpretację

\footnotetext{
${ }^{11}$ Ibidem.

${ }^{12}$ O. Kolberg, Chetmskie, t. 2, Kraków 1891, s. 195.

${ }^{13}$ Muzeumetnograficzne.rzeszow.pl, Strój ślubny, http://ubioryludowe.muzeumetnograficzne. rzeszow.pl/stroj-slubny/ [dostęp: 1 IX 2021].

${ }^{14}$ Polska pieśń ludowa. Wybór, oprac. J.S. Bystroń, Kraków [1921], s. 4.
} 
sugeruje również wcześniejsza fraza: „Żebyś ty chmielu na tyczki nie lazł, / Nie robiłbyś ty z panienek niewiast". Chmiel występuje tu jako metonimia męskiego popędu seksualnego, a jego wspinanie się na tyczki to eufemistyczne określenie aktu płciowego. Zatem w utworze tym posłużono się subtelną alegorycznością pojęć wianek oraz chmiel.

$\mathrm{W}$ innej, równie starej pieśni weselnej spisanej przez Oskara Kolberga ${ }^{15}$, zatytułowanej Łado, również mowa o wianku jako darze panny młodej dla męża:

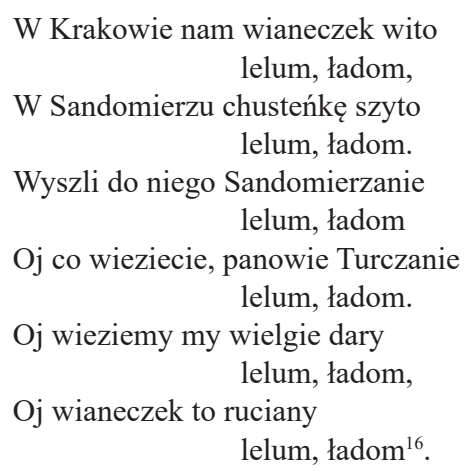

Z tekstu wynika, iż pochodząca z Krakowa panna młoda ma poślubić mieszkańca Sandomierza. Zarówno symbol dziewictwa (wianeczek), jak i małżeństwa (chusteńka) wyrażone są formami deminutywnymi, co świadczy o pozytywnym ładunku emocjonalnym w odniesieniu do rytuału przejścia. Ruciany wianek nazwany jest darem i określony intensyfikującym epitetem wielki, co ma podkreślić, iż w kulturze ludowej dziewictwo postrzegane było jako zjawisko niezwykle cenne, o czym wspomina też Ryszard Tomicki: ,na poziomie werbalizowanej świadomości społecznej zachowanie dziewictwa uważano za wartość"17.

Podobny sposób obrazowania utraty dziewictwa - jako utraty wianka - można dostrzec choćby w pieśni Hej, przyjechali deputaci z wojny, spisanej przez Kolberga, który zakwalifikował ją do tak zwanych pieśni zalotnych:

[...] Skoro w nocy po północy, po pierwszej godzinie, obróćże się, moja panno, twą twarzyczką do mnie.

Nie będę się obracała, bo mnie główka boli, straciłam se swój wianeczek, to dla twojej woli.

[...] Żebym wiedział, żebym wiedział, że to twoja cnota, kazałbym ci inszy uwić ze szczerego złota. [...]

\footnotetext{
${ }^{15}$ O. Kolberg, Lubelskie, cz. 1, Wrocław-Poznań 1962 („Dzieła wszystkie”, t. 16), s. 219.

${ }^{16}$ Utwór cyt. za: Polska pieśń ludowa..., op. cit., s. 53.

${ }^{17} \mathrm{R}$. Tomicki, Norma, wzór $i$ wartość w życiu seksualnym tradycyjnych społeczności wiejskich w Polsce, „Etnografia Polska” 1977, t. 21, z. 1, s. 43-72.
} 
Choćbyś ty się przeglądała z rana do wieczora, już nie będziesz taką panną, jakąś była wczora. Wczora<j>ś była jak lilija, jak różowy kwiatek, a dzisiajeś taka blada jak zwiędły bławatek.

[...] Choćbyś ty się sznurowała złotem i perłami, już nie będziesz łaski miała przed kawalerami ${ }^{18}$.

W tym przypadku metaforyczna utrata wianka zostaje wyjaśniona bezpośrednio w tekście, a wianek i cnota potraktowane są metonimicznie. Co więcej, znów mamy tu przykład postrzegania dziewictwa jako wartości. Z pieśni wynika, że dziewczyna po utracie wianka już nie będzie taką panną, jaką była poprzednio. Świadczą o tym porównania do lilii czy różowego kwiatka skontrastowane z komparacją jak zwiędly blawatek. Bohaterka pieśni pozbawiona tak cennej moralnej wartości straci szacunek mężczyzn. Nie będzie porównywana do kwiatu lilii, który jest popularną alegorią niewinności i czystości seksualnej. Jej rola w społeczeństwie zostanie zdeprecjonowana.

W pieśni, również spisanej przez Kolberga, Oj $i$ w ogródeczku bohaterami są Jaś i Kasia. Młodzi się spotykają, lecz wkrótce mężczyzna postanawia opuścić dziewczynę. Utwór przyjmuje formę dialogu między byłymi kochankami:

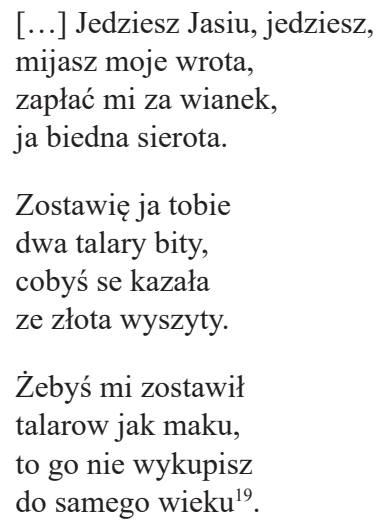

W tym utworze wianek także symbolizuje dziewictwo. Porzucona przez ukochanego Kasia ma poczucie straty, jest świadoma, że mężczyzna odebrał jej coś bardzo cennego, czego nie można kupić. Bohaterka hiperbolizuje swoje poczucie opuszczenia, określając się mianem sieroty, co wywołuje negatywne asocjacje, takie jak: samotność, bezradność, brak miłości. Epitet biedna intensyfikuje owe skojarzenia. Okazuje się, że nic nie jest w stanie zrekompensować dziewczynie utraty dziewictwa. Chłopiec oferuje dwa talary, podkreśla ich wartość, mówiąc,

${ }^{18}$ O. Kolberg, Tarnowskie-Rzeszowskie, oprac. J. Burszta, B. Linette, Wrocław-Poznań 1967 („Dzieła wszystkie”, t. 48), s. 109-110.

${ }^{19}$ Ibidem, s. 151. 
iż Kasia może za nie wyszywać złotymi nićmi. Dziewczyna jednak ma świadomość, że to za mało. Komparacja talarów jak maku, charakterystyczna dla wiejskiego sposobu obrazowania, jest próbą pokazania, że nie ma takiej sumy pieniędzy, która byłaby warta hańby - mak w tym kontekście symbolizuje wielość. Oj i w ogródeczku to kolejny utwór, w którym podkreślono wysoką pozycję aksjologiczną czystości przedmałżeńskiej oraz wyższość wartości moralnych nad materialnymi.

Pieśni są wyrazem ludowego światopoglądu, systemu wartości. Zauważamy w nich, że odpowiedzialnością za przedślubną utratę dziewictwa najczęściej jest obarczana kobieta. Jednak niektóre teksty wskazują winę mężczyzny. Przykładem jest spisany przez Kolberga (Zadwórze) utwór Kalina:

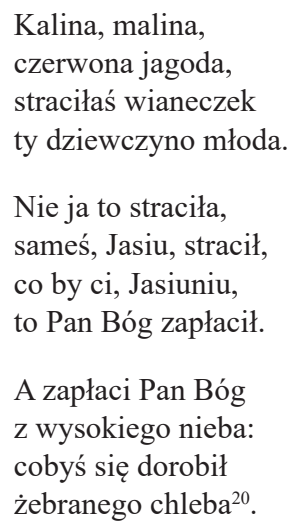

Bohaterką jest dziewczyna, która zanim poznała Jasia, była istotą niewinną, co eksplikują typowe dla ludowego obrazowania świata rzeczowniki: kalina, malina, jagoda. Wywołują one asocjacje związane z młodym wiekiem, świeżością i niewinnością. W drugiej i trzeciej strofie do głosu dochodzi bohaterka i jej wypowiedzi przyjmują formę złorzeczenia. Mają one charakter ironiczny, bowiem zapłata, której oczekuje od siły wyższej, czyli Boga, w omawianym kontekście nabiera przeciwstawnego znaczenia niż wskazuje dosłowna semantyka wymienionego leksemu. W świadomości ludowej złe uczynki zazwyczaj implikują karę i tak jest w tym przypadku, przynajmniej w sferze życzeniowej. Dziewictwo i tu podlega waloryzacji, tyle że jego koszty poniesie mężczyzna, który odebrał dziewczynie ten cenny dar.

W pieśniach ludowych współodpowiedzialna za cnotliwość panny często była jej rodzina (rzadziej matka, częściej ojciec i brat). Przykładem może być znana w wielu wersjach piosenka Podolanka. Poniżej cytuję fragment popularnej i nadal śpiewanej w okolicach Przemyśla wersji:

${ }^{20}$ O. Kolberg, Ruś Czerwona, cz. 2, z. 1, oprac. W. Kuraszkiewicz, B. Linette, M. Tarko, Wrocław-Poznań 1979 („Dzieła wszystkie”, t. 57/1), s. 293. 
Na Podolu biały kamień $(2 \mathrm{x})$
Podolanka siedzi na nim $(2 \mathrm{x})$
Przyszedł do niej Podolanek $(2 \mathrm{x})$
Podolanko, daj mi wianek $(2 \mathrm{x})$
Dałabym ci wianek dała $(2 \mathrm{x})$
Gdybym braciszka nie miała $(2 \mathrm{x})$.

Znów wianek staje się substytutem dziewictwa, ale jego głównym strażnikiem jest brat. Odpowiedzialność rodzeństwa (męskiego) za dobre prowadzenie się dziewczyny przewyższa rolę ojca. Wskazuje na to inna wersja tej samej piosenki:

Przyszedł do niej Podolaniec,

Podolanko, daruj wieniec.

Ja bym Tobie darowała,

Żebym ojca się nie bała.

Ni tak ojca, jako brata,

Bo brat bije gorzej tata. (DG, Minkowce) $)^{21}$

Pieśń obrazuje ludowe imago mundi - akceptowalność kar cielesnych za niemoralne prowadzenie się. Według wiejskiej aksjologii mają one uchronić młodą kobietę przed bardziej drastycznymi konsekwencjami utraty dziewictwa.

Są to jedynie nieliczne przykłady pieśni ludowych, w których wianek symbolizuje czystość przedmałżeńską. Ów motyw jest niezwykle popularny w tego typu twórczości. Jerzy Bartmiński dokonał jego analizy statystycznej, dowodząc, iż leksem wianek, ,jest jednym z dwudziestu najczęściej pojawiających się w tekstach rzeczowników"22.

Wianek jako symbol dziewictwa pojawia się nie tylko w obyczajach czy pieśniach ludowych. Jest także elementem przysłów, które zebrał Oskar Kolberg. Stąd wiemy, że frazeologizm umrzeć $w$ wianku oznacza pozostanie panną na całe życie. Przy okazji warto dodać, że pannom złożonym do trumny zakładano czasem wieniec na głowę, najczęściej był on upleciony z barwinka. Innym związkiem frazeologicznym podanym przez owego etnografa i przez niego wyjaśnionym jest dać komu wieniec grochowy. Zwrot ten oznacza odmówienie ręki pretendentowi do małżeństwa. „Gdy panna odmówiła kawalerowi ręki, przypinano grochowy wieniec do powozu lub posyłano do mieszkania" ${ }^{23}$. O obyczaju tym wspominają również Adam Fischer ${ }^{24}$ oraz Władysław

${ }^{21}$ M. Ancypo-Szeloch, ,, Caly mój majątek: wianeczek i kosa”. Stereotyp ,, wianka” w pieśniach ludowych powiatu sokólskiego, [w:] Socjolekt - idiolekt - idiostyl. Historia i wspótczesność, red. U. Sokólska, Białystok 2017, s. 24 (dostępne online: https://repozytorium.uwb.edu.pl/jspui/handle/11320/9699 [dostęp: 1 IX 2021]).

${ }^{22}$ Cyt. za: ibidem, s. 11.

${ }^{23}$ O. Kolberg, Przysłowia, oprac. i red. S. Świrko, Wrocław-Poznań 1967 („Dzieła wszystkie”, t. 60), s. 474.

${ }^{24}$ Rośliny w wierzeniach i zwyczajach ludowych. Stownik Adama Fischera, red. M. Kujawska et al., Wrocław 2016, s. 155. 
Kopaliński $^{25}$. O jego symbolicznej wykładni decyduje składnik wianka, czyli grochowina. Natomiast wieniec uwity ze słomy był szyderczą, obelżywą alegorią utraty dziewictwa. Wspomina o tym między innymi Piotr Kowalski: „Jeszcze niedawno w tradycjach słowiańskich spotykano praktykę zakładania bądź przyczepiania słomianych wieńców pannie, która przedwcześnie utraciła dziewictwo. Jałowość wysuszonej słomy odpowiadała sytuacji obalonego porządku taksonomicznego $[\ldots]^{\text {"26. }}$. Składniki takie jak słoma czy grochowina mają pejoratywny wydźwięk, ponieważ już podczas tworzenia, czyli wicia wieńca, były martwe, pozbawione mocy. I tym różniły się od żywych roślin, w których mimo ususzenia wianka pozostawała „,czarowna” siła. Zatem w określonym kontekście kulturowym grochowina czy słoma były pozawerbalnym komunikatem o jałowości starań lub braku wartości. Anna Brzozowska-Krajka twierdzi wręcz, iż „wszystko to, co wysuszone i bezpłodne, traktowano w myśleniu magicznym jako metonimię śmierci" ${ }^{27}$.

Współcześnie, pomijając próby rekonstrukcji dawnych zwyczajów, wianek wciąż się pojawia w naszej kulturze i nadal funkcjonuje jako alegoria dziewictwa, niewinności. W kulturze chrześcijańskiej dziewczynki przystępujące do pierwszej komunii lub sypiące kwiatki w uroczystość Bożego Ciała noszą na głowach wianuszki.

Wianek pełnił istotną funkcję w rytuałach przejścia takich jak komunia, ślub, inicjacja seksualna. Równie ważnym wydarzeniem był pogrzeb. Okazuje się, że wieniec nie tylko zakładano na głowę zmarłym pannom, ale był on darem pogrzebowym wkładanym do trumny. „Jeszcze od babci kiedyś słyszałam, że te wianuszki po uschnięciu, po wyschnięciu, to dawało się, jak umierał zmarły. Kadziło się tymi wianuszkami tego nieboszczyka albo dawało mu się do głów, to znaczy pod poduszkę (Urszula Marzec, Maruszewiec, TL, 1997)"228.

Rola wianka była istotna nie tylko w obrzędach przejścia w porządku egzystencjalnym, ale też w cyklu wegetacyjnym, sakralnym oraz życiu codziennym. Jeden z ważniejszych obrzędów w cyklu rocznym stanowiło święto plonów, czyli dożynki. Synonimiczne nazwy to wieńcowe i wieniec, ponieważ głównym atrybutem tych obrzędów był - i nadal jest - omawiany rekwizyt. Stanisława Niebrzegowska-Bartmińska zalicza wieniec dożynkowy do przedmiotów rytualnych ${ }^{29}$. Upleciony ze zbóż takich jak żyto, pszenica, jęczmień, owies, czasem z dodatkiem jarzębiny, bobu i owoców asocjuje urodzaj, obfitość i dostatek. Noszono go po polach, stanowił rodzaj dziękczynienia za dobre plony i zapowiedź przyszłorocznych. Dawniej zanoszono go też do domu gospodarza lub do kościoła. Obrzędom

\footnotetext{
${ }^{25}$ Hasło: wieniec, [w:] W. Kopaliński, Stownik mitów i tradycji kultury, Warszawa 1987, s. 1280.

${ }^{26}$ P. Kowalski, op. cit., s. 591.

${ }^{27}$ A. Brzozowska-Krajka, Symbolika dobowego cyklu powszedniego w polskim folklorze tradycyjnym, Lublin 1994, s. 175.

${ }^{28}$ Teatrnn.pl, Etnografia Lubelszczyzny - cykl roczny w życiu wsi-czerwiec, http://teatrnn.pl/ leksykon/artykuly/etnografia-lubelszczyzny-cykl-roczny-w-zyciu-wsi-czerwiec/ [dostęp: 1 IX 2021].

${ }^{29}$ S. Niebrzegowska-Bartmińska, op. cit., s. 208.
} 
tym towarzyszyły liczne pieśni, w których pojawiał się wieniec jako symbol urodzaju. Oskar Kolberg opisał dożynki obchodzone w okolicach Przemyśla pod koniec XIX w. Otóż żeńcy układali ostatnich dziewięć snopów zboża na leżących na ziemi sierpach, a młode żniwiarki wybierały z tych snopów kłosy i wiły wieniec. Następnie jedna z nich, zwana mołodą lub mołodycą, zakładała go na głowę i była prowadzona przez całą gromadę do dworu, by wręczyć symbol urodzaju gospodarzowi i tam biesiadować. Wydarzeniu towarzyszyły pieśni, w których żniwiarze domagali się nagrody za ciężką pracę:
[...] Wyjdy panojku do nas, wykup se winec u nas.
Jak ne wyjdesz wykupyty,
pijdemo ho prepyty.
Za boczku horyłoczki,
za dwa horcy pywa $[\ldots]^{30}$.

Zatem wieniec dożynkowy powinien zostać wykupiony, a nagrodą ma być obfity poczęstunek. Rekwizyt staje się w tym przypadku hiponimem, ponieważ żeńcy w znaczeniu dosłownym domagają się zapłaty za przyniesiony przedmiot, ale w rzeczywistości oczekują zadośćuczynienia za ciężką kilkudniową pracę w polu.

Współcześnie kobiety nadal wiją ze zbóż wieńce dożynkowe. Następnie uroczyście zanosi się je do kościoła, składając podziękowania za plony. Tyle że owe atrybuty urodzaju zazwyczaj są już pozbawione kolistego kształtu, a więc zatracają swoje pierwotne znaczenie.

Wianek jako koło pełni w kulturze ludowej funkcję apotropeionu. Piotr Kowalski podkreśla jednak, że „Skuteczność działania magicznego nie wymaga rzeczywistego okalania chronionego terenu. Warunkiem wystarczającym może być umieszczenie apotropeionu (np. w postaci koła) na granicy bądź w miejscu przejścia między orbis interior a orbis exterior" ${ }^{\prime 31}$. Dlatego wianki zawieszano najczęściej na ścianach domostw, głównie nad progiem lub w pobliżu okna. Jak podaje Słownik starożytności stowiańskich w przeszłości wiklinowe wieńce zakopywano jako ofiarę zakładzinową przy budowie domu ${ }^{32}$. W „Etnografii Polskiej” czytamy, iż wianuszki „umieszczano w sąsieku, aby zapewnić sobie dobre plony i chronić przed urocznymi oczami" ${ }^{33}$. Ten sposób przechowywania magicznego atrybutu jest stosowany także współcześnie i znany z autopsji. Tyle że sąsiek najczęściej zastępuje spiżarnia lub inne pomieszczenie, gdzie przechowuje się zapasy żywności.

Autor Leksykonu - znaki świata zauważa: „Obok kształtu wieńca efektywność środka magicznego oparta była jeszcze na wyborze odpowiedniego

${ }^{30}$ O. Kolberg, Przemyskie, wyd. I. Kopernicki, Wrocław-Poznań 1964 („Dzieła wszystkie”, t. 35), s. 45.

${ }^{31}$ P. Kowalski, op. cit., s. 592.

${ }^{32}$ Słownik starożytności słowiańskich, t. 7: Y-Ż, red. G. Labuda, Z. Stieber, Warszawa 1982, s. 53.

${ }^{33}$ Za: P. Kowalski, op. cit., s. 592-593. 
surowca, z którego go wyplatano"34. Zatem funkcje magiczne przypisywano ziołom wchodzącym w skład wieńca, a ich przestrzenna kompozycja warunkowała dodatkową skuteczność. Kolejnym nośnikiem intensyfikującym funkcjonalność wianka w ludowej świadomości był czas, a konkretnie czas sakralny. Powiązanie go z danym rekwizytem budziło przekonanie o transcendentnych właściwościach uświęconego przedmiotu. Jest to przykład kontaminacji wierzeń pogańskich z chrześcijańską religijnością i jej przykłady można zauważyć także współcześnie. Czas sakralny, warunkujący magiczne właściwości roślinnego splotu to przeważnie oktawa Bożego Ciała oraz Wniebowzięcie Najświętszej Maryi Panny (potocznie Matki Boskiej Zielnej). Wierzono, że poświęcone w tym okresie wianki chronią przed wszelkiego rodzaju złem. Zjawisko zła najczęściej utożsamiano z klęskami żywiołowymi (najbardziej obawiano się gradu i uderzeń piorunów), urokami, chorobami i demonami. W Stowniku Adama Fischera opisano między innymi wierzenia z okolic Przeworska na Podkarpaciu: „[...] na Boże Ciało święcone są podczas sumy wianki z bagna, macierzanki, szałwii, tureckiego ziela, leszczyny, ostu roztrzepanego, rozchodnika i żółcienia. Wianki te obnoszą miejscowi podczas procesji, uważając to za jeden z głównych warunków późniejszej skuteczności tych roślin. Kadzą nimi izby i bydło, a resztę przechowują za strzechą" ${ }^{35}$.

Ziołami, którym przypisywano magiczne właściwości apotropeiczne i wykorzystywano je do splotu, były między innymi lilia, lubczyk, melisa, hyzop lekarski zwany józefkiem, bylica, leszczyna, pokrzywa, przywrotnik, piwonia, róża, rumianek, mięta, stokrotka, wrotycz, macierzanka, barwinek, czarny bez, boże drzewko, bławatek, kwiat koniczyny, bagno, rozchodnik. Wierzono, że okadzanie domu „czarownymi” ziołami poświęconymi w czasie sakralnym i uwitymi w wianki chroni przed destrukcyjnymi skutkami burzy. Wspomina o tym Kazimierz Moszyński: „Podkurzanie takimi wiankami w celu rozpędzenia chmur występuje istotnie u Słowian (np. w Polsce)"36. Podobne informacje podają Oskar Kolberg i Adam Fischer ${ }^{37}$. Jednym z ciekawszych przykładów potwierdzających apotropeiczne właściwości poświęconego wianka w obliczu zagrożenia, jakie niesie burza, jest zapis magicznych właściwości przywrotnika pospolitego: „Przywrotnik należy do tych ziół, które święci się wraz z innymi na święto M.B. Zielnej oraz w wiankach na Boże Ciało. Takie święcenie ma moc odwracania burzy i grzmotów, a stąd też zdaniem ludu pochodzi jego nazwa nawrotek (od nawracania chmur deszczu) albo grzmotnik w celu odpędzania grzmotów. Wianuszkami z nawrotka odkurzają całe obejście przeciw burzy (Międzyrzec, Bóbrka, Kielce, Krakowskie) albo też

\footnotetext{
${ }^{34}$ Ibidem, s. 592.

${ }^{35}$ Rośliny w wierzeniach i zwyczajach ludowych. Stownik Adama Fischera, op. cit., s. 340.

${ }^{36} \mathrm{~K}$. Moszyński, op. cit., s. 314.

${ }^{37}$ O. Kolberg, Chetmskie, op. cit., s. 185; Rośliny w wierzeniach i zwyczajach ludowych. Stownik Adama Fischera, op. cit., s. 199, 351.
} 
wianek z tego ziela zawieszają w oknie (Częstochowa)" ${ }^{38}$. Okadzanie ziołami można wytłumaczyć wiarą w magię sympatyczną, ponieważ burzowe chmury utożsamiano $\mathrm{z}$ dymem.

Innym wytłumaczeniem jest utrwalone w świadomości ludowej przekonanie, iż za zjawiska atmosferyczne, a zwłaszcza destrukcyjne, odpowiadają siły demoniczne. Te natomiast także wypędzano przez rytuał okadzania. Liczne przykłady owych działań ochronnych z użyciem apotropeionu w postaci wianka podaje Leonard Pełka w Polskiej demonologii ludowej. Oto jeden z nich: „Palili przeciw chmurom wianki z rozchodnika i innych ziół, które były poświęcone na Boże Ciało. Z której strony szła chmura, tam chodzili i okadzali. Również gromnicę święconą się paliło"39. Podobna relacja dotyczy konkretnie chmur gradowych: „Do zatrzymywania chmur gradowych mówiono modlitwy, stawiano na oknie gromnice, palono zioła z wianków i kadzono nimi w stronę idącej chmury" ${ }^{\prime 40}$. Dalej w relacji czytamy: „Gdy zbliżały się do wsi chmury burzowe, ludzie palili święcone gromnice, spalali pod kuchnią święcone wianki (żeby dym szedł do góry), wynosili obraz świętej Agaty i łopatę od chleba przed dom. Obecnie też tak robią" ${ }^{\prime 1}$. Odnajdujemy też przykłady wierzeń w apotropeiczne właściwości poświęconego w Boże Ciało wianka, ale bez konieczności spalania go: „Aby ustrzec się od piorunów, palono w czasie burzy gromnice, rozrzucano wokół domu wianki z rozchodnika, święcone w Boże Ciało. Byłam świadkiem takiego zabiegu u jednej gospodyni w Korytkowie Małym. Było to około pięć lat temu. Sposób ten jest niezawodny"42. Kolejną relację Pełka przytacza z opracowania Wierzenia w Klonowej w pow. sieradzkim Wandy Drozdowskiej: „W oktawie Bożego Ciała gospodynie splatają z ziół nieparzystą liczbę wianków, które następnie zanoszą do poświęcenia do kościoła. Poświęcenie nadaje im oprócz wartości leczniczych moc chronienia przed burzą i piorunami, dlatego wianki te zawieszają na zewnętrznej stronie domu i budynków gospodarczych" ${ }^{43}$. Drozdowska zalicza tę praktykę do czynności związanych z określonymi świętami kościelnymi, w tym przypadku znów mamy przykład łączenia funkcji wianka z okresem sakralnym Bożego Ciała. Autorka Wierzeń w Klonowej wymienia również przykłady działań magicznych wykonywanych doraźnie i tu znów pojawia się nawiązanie do działań apotropeicznych w obliczu burzy: „Trzykrotne kruszenie ziela święconego z wianków do ognia płonącego w piecu, bo gdy ziele święcone wyleci z dymem z komina,

\footnotetext{
${ }^{38}$ Rośliny w wierzeniach i zwyczajach ludowych. Stownik Adama Fischera, op. cit., s. 278.

${ }^{39}$ L.J. Pełka, Polska demonologia ludowa, Warszawa 1987, s. 40. W publikacji wykorzystano materiały z Archiwum Katedry Etnografii i Etnologii Wydziału Humanistycznego Uniwersytetu im. M. Curie-Skłodowskiej w Lublinie (materiały z badań terenowych prowadzonych w latach 1962-1965).

${ }^{40}$ Ibidem, s. 41.

${ }^{41}$ Ibidem.

${ }^{42}$ Ibidem.

${ }^{43}$ W. Drozdowska, Wierzenia w Klonowej w pow. sieradzkim, „Łódzkie Studia Etnograficzne” 1960 , t. 2, s. 149-165, cyt. za: ibidem, s. 42.
} 
rozegna chmury nad zagrodą i piorun w dom nie trzaśnie"44. Pełka słusznie zwraca uwagę, że ludowe rytuały, takie jak , palenie wianków święconych w dniu Bożego Ciała, jak również zatykanie ich za belki na strychu, wieszanie w oknach i u powały izby oraz rozrzucanie wokół domu to echo dawnych słowiańskich wierzeń religijnych" ${ }^{45}$. W utrwalonych w chrześcijaństwie wierzeniach ludowych wciąż widoczne są wpływy wierzeń pogańskich. Przypisywanie ziołowym wiankom funkcji magicznej i apotropeicznej potwierdza to zjawisko.

Zło, które zagrażało i nadal zagraża człowiekowi, to nie tylko pioruny, grad czy silny wiatr. Jedną z jego postaci jest choroba. Starano się jej unikać, odwołując się do magicznych właściwości wianka poświęconego w oktawę Bożego Ciała lub podczas uroczystości Wniebowzięcia Najświętszej Maryi Panny: „W końcowych dniach oktawy Bożego Ciała święcone są wianuszki z ziół i kwiatów (głównie rumianku, mięty, macierzanki i rozchodnika). Wianuszki te zawieszane były pod świętymi obrazami w izbie, a zawarte w nich zioła stosowano w medycynie ludowej jako uniwersalne środki lecznicze" ${ }^{46}$. W tym przypadku znów właściwości wianka uwarunkowane są czasem sakralnym i niebagatelną rolę odgrywa umiejscowienie go w przestrzeni. Sąsiedztwo ze „świętymi obrazami” eksplikuje jego rangę i znaczenie. Powyższy przykład sugeruje, że zioła wchodzące w skład omawianego rekwizytu stanowią uniwersalne antidotum na choroby. Jednak niektórym roślinom w uświęconym splocie przypisywano korzystne działanie na konkretne schorzenia. Oto przykłady: „Święci się go [sadziec konopiasty - M.M.] w wiankach w dniu M.B. Zielnej, a następnie używa na różne choroby kobiece”"47, „Liście topinamburu $\mathrm{z}$ wianka święconego na M.B. Zielną należy przykładać na piersi w razie bólu" ${ }^{\text {"48 }}$, „Dziurawiec zwany także przez lud mylnie krwawnikiem (Achillea millefolium L.) wykrusza się z wianka święconego na M.B. Zielną, po czym wywar daje ludziom przeciw czerwonce”49, „Wywar z kocanki i innych ziół z poświęconego wianka, zmieszanych z siemieniem, rozkrojoną na czworo cebulą oraz ospą żytnią wlewa się suchotnikom do kąpieli (Dębicz, pow. Środa, Kolberg, Poznańskie I:145)" "50. We wszystkich opisanych czynnościach leczniczych użyto ziół, których właściwości zostały zintensyfikowane dzięki przestrzennej kompozycji oraz powiązaniu ich $\mathrm{z}$ czasem sakralnym.

Niektórych chorób starano się uniknąć poprzez okadzanie. Przykładem są działania magiczne przeciwdziałające chorobie skóry zwanej różą. W tym celu pleciono i palono wieniec z dzikiej róży. Potwierdzają to relacje z województwa lubelskiego:

\footnotetext{
44 Ibidem.

${ }^{45}$ L.J. Pełka, Polska demonologia ludowa, op. cit., s. 40.

${ }^{46}$ L.J. Pełka, Polski rok obrzędowy, Warszawa 1980, s. 57.

${ }^{47}$ Rośliny w wierzeniach $i$ zwyczajach ludowych. Słownik Adama Fischera, op. cit., s. 470.

${ }^{48}$ Ibidem, s. 472.

49 Ibidem, s. 147.

${ }^{50}$ Ibidem, s. 390.
} 
„Różę albo jak się rana sprzeciwi leczy okadzanie wiankiem święconej róży”51. Podobny zapis znajdujemy w książce Jak chłop u diabła pieniadze pożyczał Anny Michalec i Stanisławy Niebrzegowskiej-Bartmińskiej: „E, do kadzenia ji to dawali pić, parzyli i dawali ta święcona róża wzięli, te róże się brało do ziele - to kwiaty do wianków do ... to te święcone dopiero było kadzone tam ji dawane, parzone te, ta herbata tak parzona i dawana pić" 52 . Nazwa choroby bakteryjnej zwanej różą wywodzi się od jednego z jej objawów, czyli silnego zaczerwienienia skóry w miejscach zapalnych. Zatem ludowe leczenie schorzenia kadzidłem z rośliny o tej samej nazwie wskazuje na wpływ magii sympatycznej. W obydwu przytoczonych przykładach mowa jest o okadzaniu chorego wiankiem z poświęconej róży. Nie sprecyzowano jednak, czy czasem nadającym jej sakralny charakter są uroczystości Bożego Ciała lub Wniebowzięcia Najświętszej Maryi Panny.

Zwierzęta hodowlane były ważnymi żywicielami rodziny, w związku z czym ich stan zdrowia i witalność warunkowały życie ludzi. Z uwagi na znaczenie inwentarza, zwłaszcza bydła, troszczono się o nie podobnie jak o członków rodziny. W celu zabezpieczenia zwierząt hodowlanych przed urokami i chorobami również stosowano rytuał okadzania ziołowymi wiankami. Ważnym wydarzeniem było pierwsze wiosenne wyprowadzenie bydła na pastwiska. Od tej chwili stawało się ono bardziej narażone na złe spojrzenia, zawiść sąsiadów, choroby i inne niebezpieczeństwa, dlatego okadzano je w celach ochronnych. Taką informację podaje między innymi Stownik Adama Fischera: ,„[...] bydło zaś okadzone nimi w dniu, kiedy wygania się go po raz pierwszy na paszę, dobrze się chowa (Królówka, pow. Bochnia, woj. krakowskie, Orli Lot XVI 9-10: 154-156)"53. Wiankiem z macierzanki okadzano krowy przed i po ocieleniu lub po powrocie z pastwiska. Wierzono, że dym uchroni je przed chorobami, wpłynie na dojność zwierząt i wydajność masła (okolice Przeworska) ${ }^{54}$. Okadzanie miało także wypływać na wyrośnięcie chleba (Radzyń, woj. lubelskie) ${ }^{55}$.

Magiczną siłę wianków wykorzystywano na różne sposoby. Kawałki uświęconego wianuszka wrzucano do wody, którą pojono krowy, zwłaszcza gdy były osłabione. Niekiedy przygotowywano też z niego odwar: „Odwar ziół z wianka (z lubczykiem) święconego na Boże Ciało dawany jest do picia krowom po ocieleniu i w razie choroby" ${ }^{\prime 6}$. Wierzono, że owe rytualne rekwizyty zabezpieczają przed zepsuciem i to w znaczeniu dosłownym. Dlatego gospodynie wrzucały święcone wianki z rozchodnika i macierzanki do sitka, przez które przelewały mleko, żeby się nie psuło, albo doiły krowy, przepuszczając mleko przez wianek.

${ }^{51}$ Ibidem, s. 464.

${ }^{52}$ A. Michalec, S. Niebrzegowska-Bartmińska, Jak chłop u diabła pieniadze pożyczał. Polska demonologia ludowa w przekazach ustnych, Lublin 2019, s. 261.

${ }^{53}$ Rośliny w wierzeniach i zwyczajach ludowych. Stownik Adama Fischera, op. cit., s. 465.

${ }^{54}$ Ibidem, s. 424-425.

${ }^{55}$ Ibidem, s. 426.

${ }^{56}$ Ibidem, s. 419. 
Natomiast by przyspieszyć robienie masła, wrzucały kawałki takich splotów do naczynia, w którym je ubijano ${ }^{57}$.

Noszenie wianka na głowie to też przykład działania apotropeicznego. W przekonaniu ludu przyciągał wzrok, a tym samym zabezpieczał przed urokami. Wierzono, że uroki są przyczyną wielu chorób i złego samopoczucia. Wianek chronił właściciela przed złym spojrzeniem, a jego kolisty kształt symbolicznie oddzielał go w przestrzeni, wyznaczając bezpieczną granicę. Czynnikiem intensyfikującym magiczne działanie były składniki wieńca. „Na Podkarpaciu w okolicach Bóbrki noszono na głowie wianek z bylicy w dzień św. Jana Chrzciciela, by uchronić się przed bólem głowy przez cały rok" 58 .

Wiele przykładów noszenia wieńca jako ochrony przed rozmaitymi dolegliwościami podaje Józef Rostafiński w Zielniku czarodziejskim, kompendium wiedzy na temat przesądów związanych z roślinnością. Autor korzystał z herbariów, zielników i opracowań wydawanych w stuleciach XVI-XVIII. W opracowaniu Rostafińskiego czytamy fragmenty Zielnika Szymona Syreniusza na temat mięty polej, z której uwity „wieniec noszony na głowie chroni od zawrotu”, 59 , a z cząbru „od zapomnienia nad przyrodzenie (szaleństwa)" ${ }^{60}$. Natomiast Marcin z Urzędowa w Herbarzu polskim z 1595 r. doradzał noszenie wieńców z takich ziół jak koszyczko [werbena pospolita - M.M.], matki bożej włoski mniejsze [zanokcica skalna - M.M.] i polej, by uśmierzyć ból głowy ${ }^{61}$.

Również bydłu zakładano na rogi wieńce w celach apotropeicznych. W bibliotece multimedialnej stworzonej przez lubelski Teatr NN w dziale „Historia mówiona" można znaleźć wiele przykładów polskich obyczajów i wierzeń. Wśród nich są relacje dotyczące tego zjawiska. „A to było jak wyprowadzali krowy. To na rogach krowom robili wianki i, i tylko żeby było z wianków tych, co w Boże Ciało święcone, żeby tam jakaś cząstka była w tych wiankach, bo to wierzyli, że jak to będzie się taka krowa pasła $\mathrm{z}$ wiankiem, to ktoś najdzie to spojrzy najpierw na wianek, a potem na wymię i, i zadziwi się: «Na co ten wianek?» To już nie urzeknie wtedy" ${ }^{2}$. Przykład ten wskazuje także powiązanie właściwości przedmiotu z czasem sakralnym. Pojawia się tu wyjaśnienie przesądu dotyczącego ochrony przed urokami. Wianek, podobnie jak czerwone wstążki, powinien przyciągać spojrzenia i tym samym chronić jego właściciela przed urokiem.

Wierzono, że święcone ziołowe wianki zabezpieczają zagony kapusty i lnu przed szkodnikami (w okolicach Iwonicza) ${ }^{63}$. Zanoszono je też na pola, gdzie

\footnotetext{
${ }^{57}$ Ibidem, s. 286.

${ }^{58}$ Ibidem, s. 109.

${ }^{59}$ J. Rostafiński, Zielnik czarodziejski to jest zbiór przesądów o roślinach, Sandomierz 2018, s. 57.

${ }^{60}$ Ibidem.

${ }^{61}$ Ibidem, s. 98.

${ }^{62}$ Teatrnn.pl, Wianki chronity od uroków - Czesław Maj - fragment relacji świadka historii, http://biblioteka.teatrnn.pl/dlibra/dlibra/doccontent?id=46363 [dostęp: 1 IX 2021].

${ }^{63}$ Rośliny w wierzeniach i zwyczajach ludowych. Stownik Adama Fischera, op. cit., s. 409.
} 
rósł groch albo bób. Uwite z paproci i poświęcone w Boże Ciało chroniły przed szkodnikami stodoły wypełnione zbożem: „W pow. Bochnia paproć święcą na Boże Ciało i wiją z niej wianki, które kładą po rogach stodoły, aby myszy zboża nie jadły"64.

Wianki stanowiły nie tylko rodzaj komunikacji pozawerbalnej o statusie danej osoby i pełniły funkcje apotropeiczne. Wierzono również, że są źródłem mocy oraz sił witalnych. Świadczą o tym baśnie o rusałkach, nawkach (duchach zaświatów), które chętnie przystrajały głowy kwietnymi wieńcami, a pozbawione tego elementu traciły swą demoniczną moc. O przekonaniu ludu, iż wianek jest atrybutem istot nadprzyrodzonych, głównie rusałek, świadczą między innymi Klechdy, starożytne podania i powieści ludu polskiego i Rusi Kazimierza Władysława Wójcickiego ${ }^{65}$ czy Kultura ludowa Stowian Kazimierza Moszyńskiego ${ }^{66}$. Wianki przydające mocy były domeną nie tylko świata nadprzyrodzonego. Także młode śmiertelniczki wkładały wianki na głowy, aby dodawały im sił i pomagały w przywabianiu mężczyzn. Wierzono, że sploty z określonych ziół pobudzają witalność i wzmacniają umiejętność funkcjonowania w społeczeństwie, na przykład Marcin z Urzędowa pisał, iż niezwykłe właściwości mają wianki z żółtej kocanki: „Kto chodzi w wieńcu z nich ma łaskę, miłość i wdzięczność u ludzi” ${ }^{7}$. $\mathrm{W}$ tradycji ludowej ślubny wianek wrzucano do pierwszej kąpieli pierworodnego dziecka, ,aby się szczęśliwie chowało" ${ }^{\circ 8}$ albo zaszywano fragmenty ślubnego wieńca w rogi poduszek, by zapewnić rodzinie szczęście ${ }^{69}$. Wszystkie te przykłady świadczą o przypisywaniu wiankom właściwości magicznych.

Wieniec pełnił w kulturze ludowej także funkcję wróżebną. Taka rola omawianego rekwizytu również była uwarunkowana czasem, który w okresie przedchrześcijańskim stanowił sacrum, bowiem wiązał się z przesileniem letnim. Zaadaptowany przez chrześcijaństwo jako noc świętojańska nadal pozostawał w świadomości ludzi czasem wyjątkowym, magicznym i świętym. W wigilię św. Jana panny chętnie używały wianków do różnego rodzaju wróżb, najczęściej związanych z perspektywą zamążpójścia. Kazimierz Moszyński skrupulatnie opisał te praktyki, uznając rzucanie wieńców na wodę za sposób wróżenia „specyficznie słowiański”" z nocą świętojańską, a tym samym z dawnym pogańskim obrzędem kupalnocki. „Jeżeli wianek utonie, to właścicielkę jego bliska śmierć czeka, jeśli z prądem wody popłynie wartko w dal i z oczu zginie, to zamążpójście odwlecze się na czas dalszy; jeżeli zaś dwa wianki złączą się razem, to obydwie dziewczęta połączy silna, trwała

\footnotetext{
${ }^{64}$ Ibidem, s. 255.

${ }^{65} \mathrm{~K}$.W. Wójcicki, Klechdy, starożytne podania i powieści ludu polskiego i Rusi, wybór i oprac.

R. Wojciechowski, słowo wstępne J. Krzyżanowski, Warszawa 1972, s. 235.

${ }^{66}$ K. Moszyński, op. cit., s. 602, 623.

${ }^{67}$ Cyt. za: J. Rostafiński, op. cit., s. 32.

${ }^{68}$ H. Biegeleisen, Wesele, Lwów 1928, s. 168.

${ }^{69}$ Ibidem, s. 117.

${ }^{70}$ K. Moszyński, op. cit., s. 395.
} 
przyjaźń. Ale najmilsza i najpożądańsza dla puszczającej wianek jest okoliczność, gdy wianek jej pochwyci chłopiec, bo to oznacza rychły ślub [...]. Każdy rad pochwycić wianek swej miłej, co gdy mu się powiedzie, wróży dobry koniec staraniom jego o rękę dziewczyny" ${ }^{\prime \prime}$. Jeśli w pobliżu nie było rzeki ani strumienia, rzucano wianki na drzewo: „Dziewczyna, rzucając wianek na drzewo, obraca się do drzewa tyłem i ciska wianek ponad głową. Wróżba dotyczy zazwyczaj zamążpójścia, a jej pomyślny lub niepomyślny wynik zależy od tego, czy wieniec zatrzymał się na drzewie (względnie przetrwał na nim w zawieszeniu do następnego ranka) czy też upadł na ziemię" "72. Nieudany rzut oznaczał kolejny rok czekania na zamążpójście. Mężczyzna, który podczas nocy świętojańskiej zdobył wianek ukochanej, mógł liczyć na to, iż wkrótce otrzyma go od niej w sensie dosłownym podczas zaślubin, ale także w znaczeniu metaforycznym, jako że wianek - o czym pisałam wyżej w symbolice ludowej oznaczał dziewictwo.

Człowiek z natury stara się chronić siebie oraz swoje otoczenie zarówno w sensie realnym, fizycznym, jak i transcendentnym. Przejawia się to między innymi w dbałości o miejsce zamieszkania, w trosce o jego bezpieczeństwo. W tym celu w przeszłości składano ofiarę zakładzinową pod budowę domu. Współcześnie wciąż żywą tradycją praktykowaną w budownictwie jest zawieszanie wiechy na górnych warstwach powstającego domu po każdym ważnym etapie budowy. Obecnie wiecha niekoniecznie ma postać wianka, ale dawniej był to wieniec z gałęzi drzew, na przykład sosny, świerku, topoli, klonu, i miał zapewnić powstającej budowli oraz jej przyszłym mieszkańcom pomyślność, a także pełnić funkcje apotropeiczne. W powiecie lubelskim zawieszano czasem wianki z koniczyny ${ }^{73}$. Zatem mamy tu kolejny przykład nadania wieńcowi cech szczególnych, transcendentnych.

Ludzie wciąż mają potrzebę doświadczania sacrum, życia w świecie cechującym się cyklicznością, pełnym tradycji, choć są one coraz bardziej zniekształcane, a wynika to z nieznajomości pierwotnych znaczeń pewnych gestów, rytuałów czy przedmiotów. Tak też się dzieje w przypadku atrybutu, jakim jest wianek. Panna młoda zamieniła go na welon. Okrągłe wieńce pełniące funkcję wiechy ustąpiły bukietom, a symbolem plonów podczas dożynek stały się wymyślne kompozycje ze zbóż. Mimo to człowiek wciąż poszukuje sposobów, by chronić siebie i innych, pragnie wzmacniać siły witalne, wpływać na otoczenie i swój los, chce komunikować się niewerbalnie. Te wszystkie ludzkie pragnienia są uniwersalne, a kultura ludowa stanowi skarbiec, w którym są one przechowywane. Motyw wianka jest jednym $\mathrm{z}$ wielu symboli funkcjonujących w świadomości ludowej, jawi się wręcz jako archetypiczny. Oznacza potrzebę ochrony, pragnienie witalności, dostatku i wpływania na rzeczywistość oraz chęć podporządkowania się pewnym konwencjom społecznym, zatem wpisuje się w odwieczne ludzkie dążenia.

\footnotetext{
${ }^{71}$ Ibidem, s. 396.

${ }^{72}$ Ibidem, s. 398.

${ }^{73}$ Rośliny w wierzeniach i zwyczajach ludowych. Stownik Adama Fischera, op. cit., s. 109.
} 


\section{Bibliografia}

\section{Źródla}

O. Kolberg, Chetmskie, t. 2, Kraków 1891.

O. Kolberg, Lubelskie, cz. 1, Wrocław-Poznań 1962 („Dzieła wszystkie”, t. 16).

O. Kolberg, Przemyskie, wyd. I. Kopernicki, Wrocław-Poznań 1964 („Dzieła wszystkie”, t. 35).

O. Kolberg, Przysłowia, oprac. i red. S. Świrko, Wrocław-Poznań 1967 („Dzieła wszystkie”, t. 60).

O. Kolberg, Ruś Czerwona, cz. 2, z. 1, oprac. W. Kuraszkiewicz, B. Linette, M. Tarko, Wrocław-Poznań 1979 („Dzieła wszystkie”, t. 57/1).

O. Kolberg, Tarnowskie-Rzeszowskie, oprac. J. Burszta, B. Linette, Wrocław-Poznań 1967 („Dzieła wszystkie", t. 48).

A. Michalec, S. Niebrzegowska-Bartmińska, Jak chłop u diabła pieniądze pożyczał. Polska demonologia ludowa w przekazach ustnych, Lublin 2019.

Polska pieśń ludowa. Wybór, oprac. J.S. Bystroń, Kraków [1921].

K.W. Wójcicki, Klechdy, starożytne podania i powieści ludu polskiego i Rusi, wybór i oprac. R. Wojciechowski, słowo wstępne J. Krzyżanowski, Warszawa 1972.

Teatrnn.pl, Etnografia Lubelszczyzny - cykl roczny w życiu wsi - czerwiec, http://teatrnn.pl/leksykon/ artykuly/etnografia-lubelszczyzny-cykl-roczny-w-zyciu-wsi-czerwiec/ [dostęp: 1 IX 2021].

Teatrnn.pl, Wianki chronity od uroków - Czesław Maj - fragment relacji świadka historii, http://biblioteka.teatrnn.pl/dlibra/dlibra/doccontent?id=46363 [dostęp: 1 IX 2021].

\section{Opracowania}

M. Ancypo-Szeloch, ,, Cały mój majątek: wianeczek i kosa”. Stereotyp ,, wianka” w pieśniach ludowych powiatu sokólskiego, [w:] Socjolekt-idiolekt-idiostyl. Historia i współczesność, red. U. Sokólska, Białystok 2017, s. 24 (dostępne online: https://repozytorium.uwb.edu. pl/jspui/handle/11320/9699 [dostęp: 1 IX 2021]).

H. Biegeleisen, Wesele, Lwów 1928.

A. Brzozowska-Krajka, Symbolika dobowego cyklu powszedniego w polskim folklorze tradycyjnym, Lublin 1994.

Z. Gloger, Encyklopedia staropolska, t. 4, Warszawa 1903.

W. Kopaliński, Stownik mitów i tradycji kultury, Warszawa 1987.

W. Kopaliński, Stownik symboli, Warszawa 1990.

P. Kowalski, Leksykon - znaki świata. Omen, przesą, znaczenie, Warszawa 1998.

Z. Kuchowicz, Obyczaje staropolskie XVII-XVIII wieku, Łódź 1975.

K. Moszyński, Kultura ludowa Stowian, t. 2: Kultura duchowa, cz. 1, Warszawa 1967.

Muzeumetnograficzne.rzeszow.pl, Strój ślubny, http://ubioryludowe.muzeumetnograficzne.rzeszow. pl/stroj-slubny/ [dostęp: 1 IX 2021].

S. Niebrzegowska-Bartmińska, Symbolika płodnościowa w polskim folklorze, „Etnolingwistyka. Problemy Języka i Kultury” 2016, t. 28, s. 207-226.

L.J. Pełka, Polska demonologia ludowa, Warszawa 1987.

L.J. Pełka, Polski rok obrzędowy, Warszawa 1980.

J. Rostafiński, Zielnik czarodziejski to jest zbiór przesądów o roślinach, Sandomierz 2018.

Rośliny w wierzeniach i zwyczajach ludowych. Stownik Adama Fischera, red. M. Kujawska et al., Wrocław 2016.

Stownik języka polskiego PWN, https://sjp.pwn.pl/ [dostęp: 1 IX 2021].

Slownik języka polskiego, red. W. Doroszewski, t. 9, Warszawa 1967.

Słownik starożytności słowiańskich, t. 7: Y-Ż, red. G. Labuda, Z. Stieber, Warszawa 1982.

R. Tomicki, Norma, wzór i wartość w życiu seksualnym tradycyjnych społeczności wiejskich w Polsce, „Etnografia Polska” 1977, t. 21, z. 1, s. 43-72. 